\title{
THE ANALYSIS OF RECYCLING INDUSTRY IN THE URAL FEDERAL DISTRICT Elena Silova ${ }^{1}$, Viktor Barkhatov ${ }^{2}$
}

\begin{abstract}
This article concentrates on the analysis of the recycling industry in Ural Federal District. Nowadays the problem of development of this industry is extremely important due to the need of real transition to long-term sustainable development. It is necessary to understand what enterprises have presented the industry and what problems they face now for further institutional design of ecologically sustainable development of industrial regions. These regions have serious ecological problems which need a strategy to solve them. In this article, the financial condition of Ural enterprises is analyzed and the analysis of level of market concentration and the interrelation between concentration level in industry and the financial condition of the companies is revealed. The financial analysis, analysis of concentration and statistical methods (correlation analysis) are used in this research. The information base of the research is the database FIRA PRO on the enterprises which contain such indicators such as sales revenue, net profit, number of employees, return on equity and others. The study shows that the recycling industry is characterized by rather low financial indicators. The prevailing kind of activity is processing of metals scrap. Collecting and processing of other types of resources are poorly developed. The market is characterized by moderate concentration, its level affects negatively on financial indicators of industry. Within regional economic policy it is necessary to provide measures for the stimulation of this industry in the Ural regions to develop competition in the industry.
\end{abstract}

JEL Classification Numbers: O33, O44, P25, DOI: 10.12955/cbup.v7.1376

Keywords: sustainable development, recycling industry, institutional design

\section{Introduction}

Today the development of the recycling industry in Russian regions is one of the most important issues of sustainable development. The wave of "garbage collapses" has swept since the beginning of 2018 in the central regions, and in September-October, 2018 has overflowed the Chelyabinsk region. A similar situation is a reflection of a very serious problem of insufficient development of collecting, processing and recycling industries in our economy. Annually over 60 million tons of waste are manufactured in Russia. Places of waste disposal (the main method of garbage utilization) extend annually by 300-400 thousand hectares. A system of sorting and waste recycling (according to experts, less than $4 \%$ of the total amount of garbage are processed) is almost not developed. Key industries in the Ural Federal District are metallurgical production and mechanical engineering. Therefore, the share of these industries in the total amount of produced industrial wastes is about $45 \%$. Russia strongly lags behind the leading countries of the world where a problem of waste recycling and use of secondary resources has been solved by scientists, the state and business for many decades, and these countries have achieved a significant progress in the recycling industries development.

The purpose of this work is to analyze a condition of the recycling industries in the Ural Federal District, to reveal their key problems and to offer the directions of development of this economic sector for transition to the concept of sustainable development of industrial regions. The relevance of this research is caused by the fact that a similar analysis is practically absent in domestic literature. That can be caused by extremely low level of development of this industry and its insignificance for the economy both on the national and regional levels. For stimulation of its development, it is necessary to estimate its condition for today.

\section{Data and methodology}

In the presented work, methods of financial analysis, analysis of market concentration and correlation analysis are used. The statistical database used is FIRA PRO.

In the first stage we will conduct a comparative analysis of the development of the recycling industry using the following indicators: the number of the companies, sales revenue, the net profit and average number of employees. Data are presented in Table 1.

According to Table 1, the enterprises of the Sverdlovsk and Chelyabinsk regions had the largest output, and the net profit in the first region is notably higher (almost twice). The Kurgan region has the smallest sales total revenue of recycling enterprises, a share of this region in the total amount of revenue is only $0.4 \%$. There are only 14 enterprises engaged in processing and recycling in this region. The situation in

\footnotetext{
${ }^{1}$ Chelyabinsk State University, Chelyabinsk, Russia, metod@csu.ru

${ }^{2}$ Chelyabinsk State University, Chelyabinsk, Russia, ieo-science@csu.ru
} 
the Tyumen region is interesting, in it 79 enterprises in general for 2017 have generated a total loss more than 13 million rubles (about 200 thousand dollars).

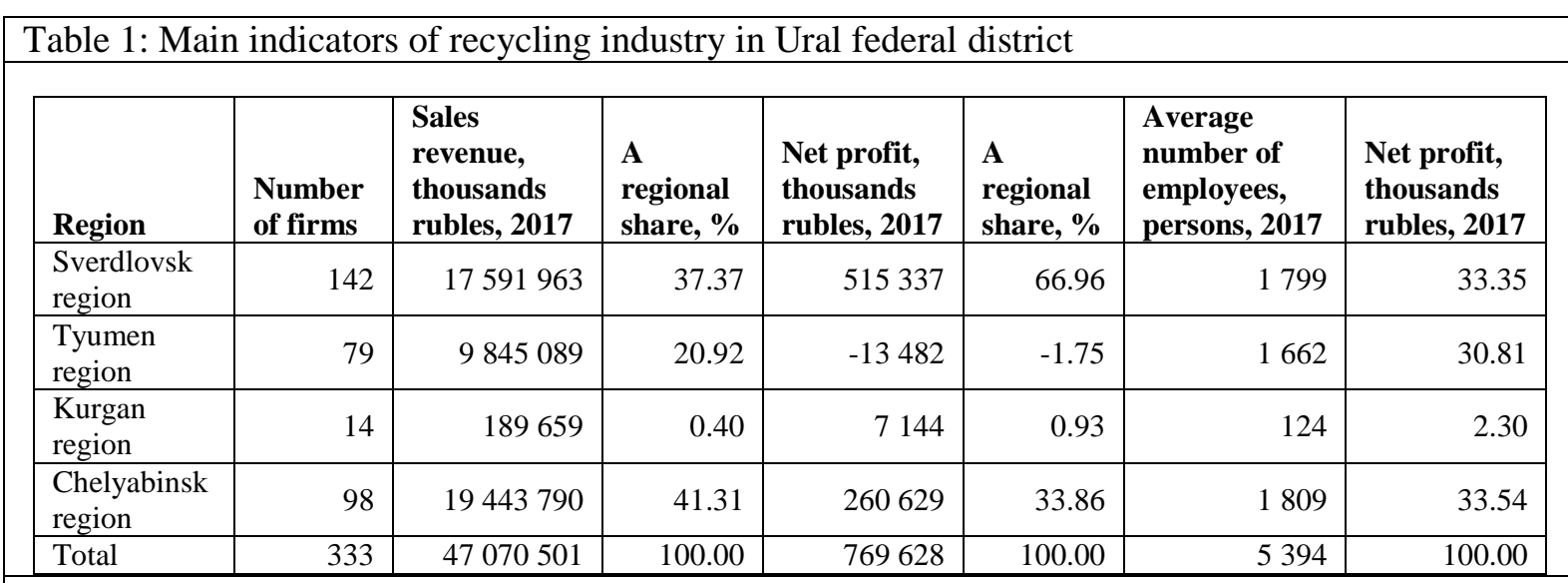

Source: evaluated by authors according to FiraPro database

At the second stage, the key financial information about the recycling enterprises is received. The authors have carried out an analysis of the most important financial indicators: share of the credits and loans in short-term liabilities, ratio loan and equity (financial stability); turnover of assets, capital productivity (business activity); profitability of equity and sales (efficiency); current liquidity. Data is presented in Table 2.

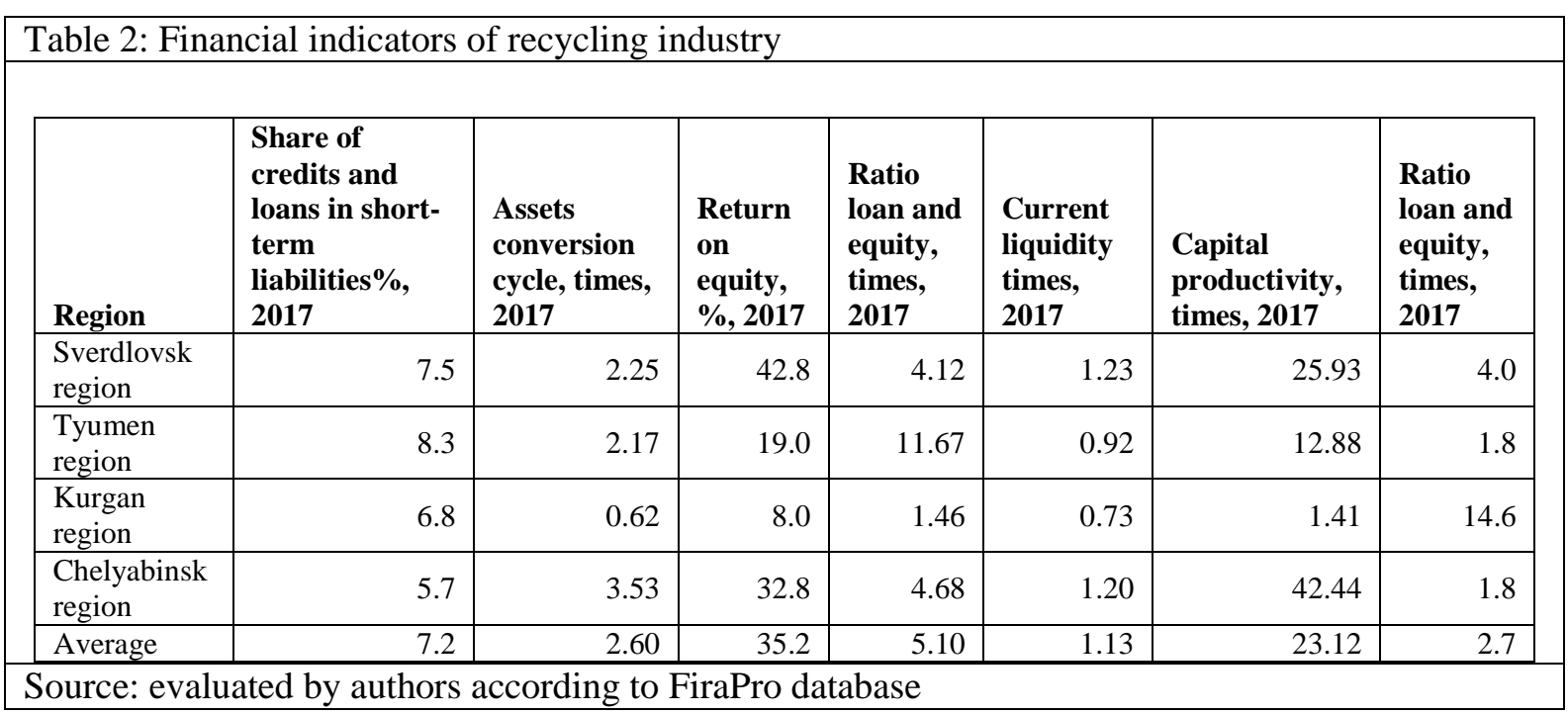

According to Table 2, the share of the credits and loans in short-term liabilities is rather small and varies from $5.7 \%$ in the Chelyabinsk region and up to $8.3 \%$ in the Tyumen region. Tyumen firms have a very high level of loan capital - it exceeds the equity volume by more than 11 times. It shows the low level of financial stability of the enterprises. Profitability of the capital is rather high at the enterprises in the Sverdlovsk (42.8\%) and Chelyabinsk (32.8\%) areas, it is connected with small values of equity. We noted one more tendency of the enterprises in this industry - micro and small enterprises which was to have no sufficient equity for investments into fixed assets. At the same time, profitability of sales is rather low, the average level is only $2.7 \%$.

At the third stage the comparative analysis of the enterprises of the Chelyabinsk and Sverdlovsk regions we carried out an analysis on the key financial result in a section of industry's subgroups (according to All-Russian Classifier of Economic Activities). Results are presented in Table 3.

The analysis shows that the waste recycling enterprises are engaged mostly in subsectors such as processing of scrap of ferrous and non-ferrous metal. First of all that is caused by the industrial structure of the studied regions. The other spheres of waste processing are presented as extremely poor, for example, there are no enterprises for waste processing of glass in the Sverdlovsk region. It demonstrates the necessity to create these directions of waste processing. 


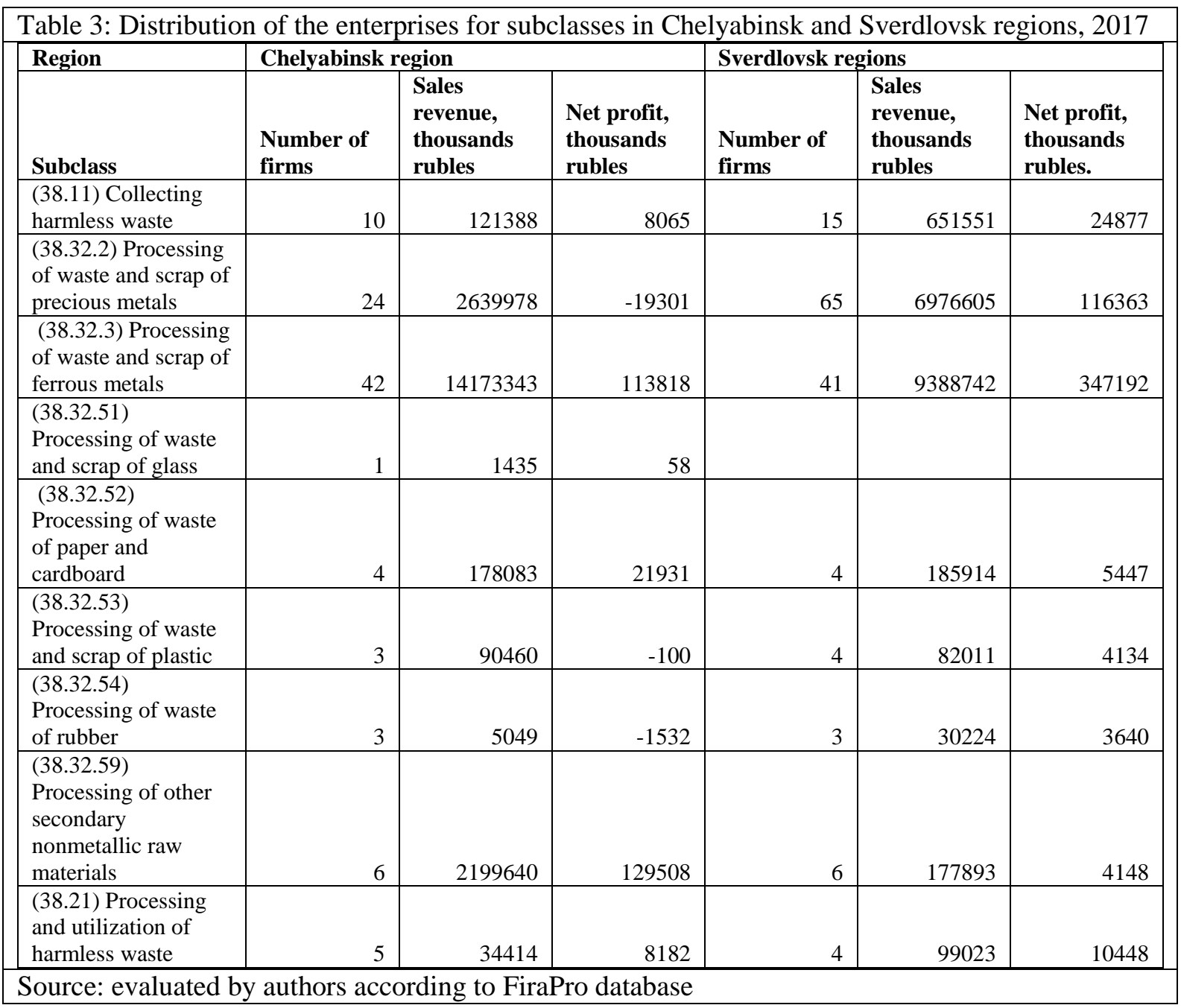

At the fourth stage of our research, concentration indicators are calculated: $\mathrm{CR}_{1}, \mathrm{CR}_{3}, \mathrm{CR}_{7}$ and $\mathrm{HHI}$. The index of concentration (1) is measured as the sum of market shares of the major companies operating in the market and allows us to estimate the concentration of production in branches of the economy:

$C R_{k}=\sum_{i=1}^{k} Y_{i}$

where $\mathrm{Yi}$-a market share of $\mathrm{i}$-that firm; $\mathrm{k}$ - number of firms for which this indicator is calculated.

Herfindahl-Hirschman index is defined as the sum of squares of shares of all firms operating in the market. General formula of calculation of the Herfindahl-Hirschman index:

$H H I=\sum_{i=1}^{n} y_{i}^{2}$

where $y_{i}$ - square of a market share.

Table 4: Market concentration indicators, 2017

\begin{tabular}{|l|r|r|r|r|}
\hline Indicators & \multicolumn{1}{|l|}{$\mathbf{C R}_{\mathbf{1}}$} & \multicolumn{1}{l|}{$\mathbf{C R}_{\mathbf{3}}$} & \multicolumn{1}{|l|}{$\mathbf{C R}_{\mathbf{7}}$} & \multicolumn{1}{l|}{ HHI } \\
\hline $\begin{array}{l}\text { Sverdlovsk } \\
\text { region }\end{array}$ & 19.68 & 37.08 & 56.6 & 732.49 \\
\hline Tyumen region & 26.4 & 55.5 & 71.26 & 1259.62 \\
\hline Kurgan region & 29.41 & 60.3 & 93.22 & 1674.8 \\
\hline $\begin{array}{l}\text { Chelyabinsk } \\
\text { region }\end{array}$ & 16.61 & 45.44 & 74.5 & 963.36 \\
\hline
\end{tabular}

Source: evaluated by authors according to regional statistic reports 
According to the obtained data, it is possible to emphasize the following features of development of the branch markets: moderate concentration (if to analyze a share of three largest companies) is revealed in the Sverdlovsk and Chelyabinsk regions. The market of the Kurgan region has the highest market concentration (the share of three companies exceeds $60 \%$, and the share of 7 firms - more than 93\%). The high level of concentration here is confirmed also by the highest level of the Herfindahl-Hirschman index (1674.8). The minimum concentration level is shown in Sverdlovsk region (732.5), and the Chelyabinsk and Tyumen regions can be characterized as regions with moderate market concentration.

At the fifth investigation stage we carried out a correlation analysis between the Herfindahl-Hirschman index and key financial indicators in a regional section. The results are shown in Table 5.

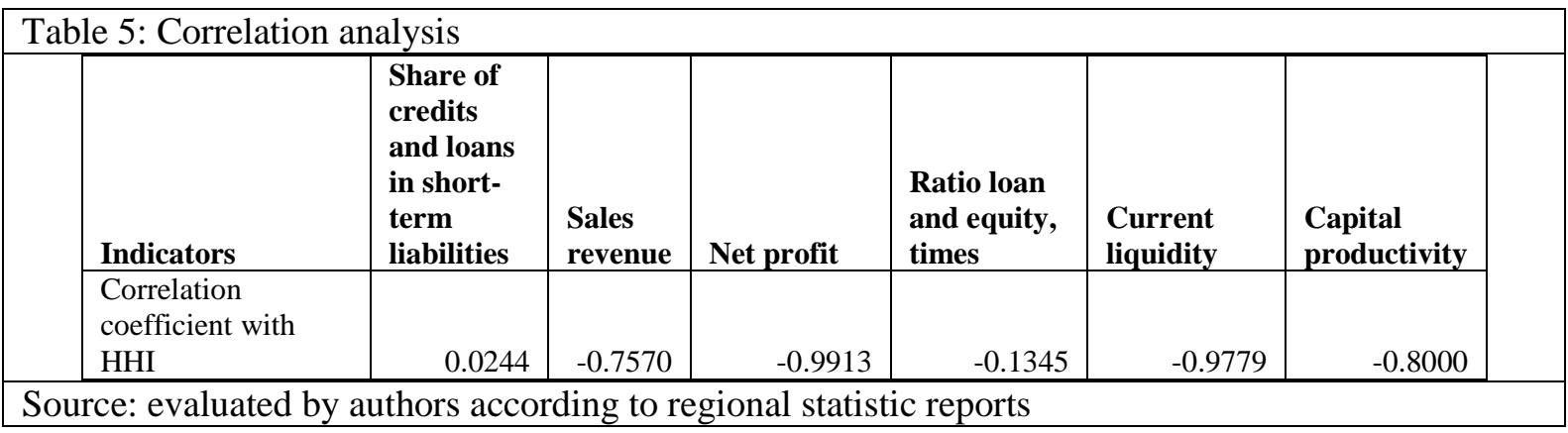

Results of the correlation analysis show the strongest feedback exists between the level of market concentration and profitability of sales, net profit, the current liquidity and capital productivity. Indicators of financial stability are poorly connected with the level of market concentration. The linear correlation coefficient between the level of concentration in the recycling market and the net profit is 0.99 , the highest value among the indicators under consideration. The reverse nature of correlation shows that the high concentration in the industry affects the key financial performance of companies, especially the level of profitability, asset capital productivity and current liquidity. The level of concentration has a slight impact on indicators such as the share of loans in short-term liabilities and the ratio of equity to debt. The concentration affects more the efficiency and business activity of enterprises. Perhaps increasing competition in the market and the arrival of new players would make the market more motivated and improve financial performance.

\section{Results and Discussion}

The problem of social and economic sustainable development has a complex cross-disciplinary character. The term "sustainable development" was widely adopted in connection with the increase in global environmental problems in the 1970s. The specified problems became a result of the unlimited growth of western market economies based on the capitalist economy and the developed "consumer society". However, according to domestic scientists this term is close to the concept "noospheres" which was studied in the works of the academician V.I. Vernadsky. The concept of sustainable development began to develop actively in an economic and political discourse after a number of international conferences of ecological orientation were carried out and the publication of the following documents occured: report "Growth limits" by the Roman Club (1972), report of the Commission of the UN "Our general future" (1987) and some others. In these documents the interrelation between economic processes, poverty and ecological crises is emphasized, and sustainable development is considered as development, which allows for the satisfaction of the needs of recent people, without depriving future generations of the opportunity to satisfy their requirements. A number of authors from the western academic circles in the 1980s to the beginning of the 1990s considered environmental problems from the point of view of the price of resources and readiness of consumers to pay for them (Arrow et al., 1999). A similar approach describes outer effects from ecological damage in categories of environmental pollution, resource depletion and health of the population. Another popular approach became the basis of the economic policy of the Netherlands in the field of sustainable development, which is the concept of "spatial environmental management" (van Herwijnen, 1999). Pressure limits which the ecosystem can maintain without irreversible damage and which need to be used for the delimitation of economic activity were studied in their papers. D. Drezner is one of the first theorists who have generalized the principles of sustainable development, but at the same time he emphasized internal discrepancy of this concept such as for the change of the relation to planet resources, it is necessary to change social 
institutes and the way of life (Drezner, 2006). M. Purvis and A. Granger made an attempt to include the new concept in the neoclassical paradigm, considering the opportunities of use of waste and resourcesaving processes. Their research explores different interpretations of sustainable development in both theory and practice, in developed and developing countries, and in rural and urban areas. It pays particular attention to the local, national and international politics of implementation, the future of climate and energy, the role of business, and different conceptions of agricultural sustainability (Purvis and Granger, 2013). The modern researches within the theory of sustainable development are connected with concepts such as the "green economy", "circular economy", and "industrial ecology". Many scientists abroad are engaged in modern studies of large industrial systems' ecologically sustainable development. Dyana Simpson researches the structure of the recycling industry and points out the dominating role of big corporations in this economic sector (Simpson, 2010). Kochan et al. (2016) and others analyze the re-cycling behavior in different countries and groups of users, using a structural equation modeling technique.

Han et al. (2018) investigate the effectiveness of various waste separation policies under the consideration of local socioeconomic contexts. The findings suggest that waste separation knowledge, social capital, free provision of sortable containers and community collecting recyclables are positively associated with household involvement in waste separation.

Kuznetsov et al. (2000) analyze the principles of sustainable development in Russia. Kamenik (2015) explores resources recycling as a new vector of Russian economic policy and many other Russian scientists deal with problems of ecologically sustainable development in domestic science. Bodrunov and his colleagues (2018) devote their papers to industrial policy. The questions connected with regional sustainable development, clustering, and the competition between regions of the Ural Federal District are deeply investigated in Tatarkin (2009), etc..

The most important direction of sudies are the works connected with the organization of the system of the return material streams (the return logistics). These problems were investigated by Beckley and Logan (1948), and Giultinian and Nwokoye (1975). The basic concept of return logistics was created by Murphy and Poist (1989) in the late eighties. In Russia, the perspective of management of the return material streams is investigated in works by Zueva and Vdovin (2011) and others.

Waste processing is a part of a strategy of sustainable development. The solution of the problem of recycling is important for industrial regions. The recycling industry is represented by a small number of enterprises. The majority of them being located in the Sverdlovsk region, the total revenue of the industry for 2017 amounted to more than 47 billion rubles (about 700000 dollars), the industry employs almost 5.5 thousand people. Net profit is small, in the Kurgan region and the industry generates a significant loss. The industry is characterized by low financial stability, the Tyumen region has the highest level of borrowed capital. Return on capital is high, especially in the Chelyabinsk and Sverdlovsk regions (more than 30\%). Sales profitability remains low. The main form of enterprises is small and micro business. Processing mainly affects metal waste, and the rest is hardly processed. The industry is characterized by moderate concentration, which negatively affects the financial performance of companies. It is characterized by rather low financial indicators. Serious investments in this industry and information support of process of collecting and sorting of garbage are necessary. These tasks have to become a priority for the solution of environmental problems in industrial regions.

\section{References}

Arrow, K., Bolin, B., Costanza, R., Dasgupta, P., Folke, C., Holling, C.S., Jansson, Levin, S., Maler, K.G., Perrings, C., Pimentel, D. (1995). Economic growth, carrying capacity, and the environment. Ecological Economics, Book 15, № 2, 91-95.

Herwijnen, M. van. (1999). Spatial Decision Support for Environmental Management. Institute for Environmental StudiesSpatial Economics. Amsterdam Publisher Tinbergen Instituut State Published.Drezner, Daniel W. (2006). The race to the bottom hypothesis: an empirical and theoretical review. Fletcher School. Tufts University, $200 \mathrm{p}$.

Purvis, M., Grainger, A. (2013). Exploring sustainable development: Geographical perspectives. (Book). Exploring Sustainable Development: Geographical Perspectives, pp. 1-401.

Simpson, D. (2010). Use of supply relationships to recycle secondary materials. International Journal of production research. Book volume: 48. Issue: 1. 227-249.

Kochan, C., Pourreza, Saba; Tran, Huguette. (2016). Determinants and logistics of e-waste recycling. International Journal of logistics management. Book volume 27, Issue 1, 52-70.

Han, H., Zhang, Z., Xia, S., Li, H. (2018). The carrot or the stick: individual adaption against varying institutional arrangements. Journal of Environmental Planning and Management. 61(4), 568-596. 
Kuznetsov, O.L., Kuznetsov, P.G., Bolshakov, B.E. (2000). The system Nature - Society - Man. Sustainable development. State scientific center of RF. Dubna.

Kamenik, L. L. (2015) Resources recycling - a new vector in economic policy of Russia Forsite «Russia»: design of a new industrial policy: Papers of Sankt-Petersboug International Economic Congress (SPEC-15), 147- 157.

Bobilev, S., Perelet, R. (2013). Sustainable development in Russia. Berlin- Sankt-Petersburg. Available at: clicr.ru>uploads/images/file_public_3427.pdf. Date: 25.01.2017.

Bodrunov, S. (2018). Noonomics. M.:Cultural revolution, 432.

Tatrkin, A. I., Tatarkin, D.A. (2009). Spontaneous territorial economic systems. Dialectics of formation and functioning. Economics. Taxes. Law. №5, 3-13.

Beckley, D.K., Logan, W.B. (1948). The retail salesperson at work, Gregg publishing, New York, NY.

Giultinian, J.P., Nwokoye, N.G. (1975). Developing distribution channels and systems in the emerging recycling industries. International Journal of Physical Distribution. Vol.6. No.1, 28-38.

Murphy, P.R., Poist, R.F. (1989). Management of logistical retromovements: an empirical analysis of literature suggestions. Transportations reseach forum, 177-184.

Zueva, O.N., Vdovin, S.S. (2011). Improvement of a technique of a research and forecasting of returnable logistic material flows. News of the Ural State Economic University. № 6 (38), 127-135. 